\title{
Biotechnology, the US-EU dispute and the Precautionary Principle
}

\author{
Henk van den Belt
}

\begin{abstract}
The international debate on biotechnology is extremely polarized. Opponents such as Greenpeace International, Friends of the Earth and other NGOs often invoke the Precautionary Principle to advance their cause. The principle is also at issue in trade disputes between the USA and the European Union. There are several versions of the Precautionary Principle in circulation. The strong version adopted by many environmentalist organizations is logically untenable, while the weaker versions espoused by the European Commission and enshrined in international treaties are rather vague and ill-defined. The contested role of the Precautionary Principle bears testimony to public ambivalence towards scientific expertise in modern risk societies. A more open and democratic decision-making process on biotechnology will not by itself resolve the underlying uncertainties. Shifting the burden of proof to the proponents of biotechnology makes sense only if the required standard of proof is also specified. The debate on the Precautionary Principle appears to be a proxy for a larger debate on the future of world agriculture.
\end{abstract}

Keywords: biotechnology; Precautionary Principle; burden of proof; public participation; scientific credibility

\section{Introduction: French GMO controversies}

In many parts of the world fierce debates on biotechnology have been raging without as yet showing any signs of abating. Recent controversies in France on 'les OGM' (organismes génétiquement modifiés or genetically modified organisms, GMOs) exemplify the many different issues that are involved in such debates.

Representatives of top-level institutions like the agricultural research establishment INRA (Institut National de la Recherche Agronomique), the Academy of Sciences and the Academy of Medicine and Pharmacy are showing increasing concern about the prevalent anti-biotech mood among the French population and its implications for the country's position in international research and industrial competition. As recently as April 2000 the charismatic activist José Bové and eight other anti-GMO militants destroyed experimental test fields planted with transgenic oilseed rape in the vicinity of Gaudiès, an act for which they were later convicted in court. In a letter to the daily newspaper Libération dated 23 September 2002, the president and the general director of INRA, Bertrand Hervieu and Marion Guillou, emphatically spoke out in favour of conducting field trials with transgenic crops as

\footnotetext{
\# Applied Philosophy Group, Wageningen University and Research Centre, Hollandseweg 1, NL-6706 KN Wageningen. E-mail: Henk.vandenBelt@wur.nl
} 
being indispensable for getting to know the real risks of 'gene flow' (Hervieu and Guillou 2002). They saw it as an obligation that a public research institute like INRA simply owed to France and its citizens: "Abandoning field tests would make France, in a certain sense, mute and blind". As a public agency, INRA also has an important part to play in any research supporting the innovative improvement of French agriculture, including biotechnology. "But we should take care that such progress is shared and approved by all the actors in the agricultural and food chain, from the farmer to the consumer". According to the president and the general director, INRA was already engaged in this 'dialogue'. They also claimed that "INRA had been the first to apply the precautionary principles [principes de précaution] to the GMO question and to put them into practice", without however explaining what this amounted to (or why the plural was being used). Finally, the two board members pointed out that INRA, together with other French research institutes, takes part in the research consortium Génoplante devoted to the study of plant genomics, in which private companies like Bayer and the seed business also participate. Thus the letter ended in upbeat fashion: "Constructive endeavour and dialogue with all the actors in the debate, sharing of orientations and results, a broad partnership [partenariat large]: these are the principles that guide our research. Let's use the opportunity offered by the debate on GMOs and on the field trials to renew the terms of the contract between science, industry and society and to finally put into place a veritable social management of innovation" (Hervieu and Guillou 2002).

Despite this invitation to co-operation, opponents of biotechnology did not grasp the outstretched hand. In October 2002 a number of critics wrote an open letter to INRA. They concluded that after the institute's leaders had spoken out and taken position in the current GMO debate, "INRA is from now on no longer a site of neutral expertise, but a partisan actor [un acteur engagé]" (Inf'OGM 2002). They maintained that the directorate's attitude even called the existence of a research institute in the service of the public good into question. The alleged need of field trials with transgenic crops to determine the true risks of gene flow was disputed; tests with nonmodified crops would do just as well to follow the spread of pollen. Moreover, the large-scale commercial introduction of transgenic crops in North America and Argentina had abundantly demonstrated that the 'contamination' of non-GM crops and wild relatives already occurs to such an extent that the continued viability of organic farming is seriously threatened. The real reason for field tests in France, the critics suggested, is not to ascertain the exact risks of inadvertent spread of foreign genes but to assess new, transgenic crop varieties under actual conditions of culture in order to facilitate their subsequent commercial introduction. The 'broad partnership' with various business firms of which the INRA directorate prided itself so much, was in the eyes of the critics nothing less than a scandalous privatization of public research institutes. While public monies contribute 70 percent of the funds for the Génoplante consortium, public representatives occupy only 50 percent of the seats in the managing board. Private companies were said to have an inordinate influence on the direction of research. "Tell me who your business partners are and I will tell you what research you are going to undertake" (Inf'OGM 2002). The critics also accused the INRA directorate of paying no more than lip-service to the need for 'dialogue' with the larger public: in fact, the findings of a citizens' conference on GMOs held in 1998 and a debate on field trials organized in 2002 by a commission of wise men were completely ignored because their outcomes did not please the proponents of biotechnology (for comments on these abortive attempts at public participation, see also Testart 2000). Finally, as regards the claim that INRA took the lead in applying the Precautionary 
Principle to the GMO question, the critics observed that while INRA had indeed instituted its own Comité d'éthique et de précaution (Comepra), the committee's report for the year 1999-2000 was almost kept as a secret and only released to the public after five months of insistent pressure. So much for INRA's self-declared policy of openness and dialogue.

After INRA, in December 2002 the Academy of Medicine and Pharmacy and the Academy of Sciences also published reports on the GMO question. While the report of the former institution counted only a few pages, the latter's report - prepared under the direction of Professor Roland Douce, director of the Institute of Structural Biology in Grenoble - was more extensive (Académie des Sciences 2002). Both reports pleaded, among other things, for lifting the existing European moratorium on the commercial introduction of new transgenic crops, in force since October 1998, and thereby aroused the ire of some environmentalist organizations. In response, the 'anti-globalist' group Attac and green watchdog organizations like OVALE (Observatoire de vigilance et d'alerte écologique) and CRII-GEN charged the authors of the two reports with having insulted science by debasing the two academies to the rank of mouthpieces for the big companies of the 'genetic-industrial and agrifood complex'. They were also accused of having exposed themselves as a fifth column in support of the Bush administration, which in January 2003 announced plans to lodge a complaint with the WTO against the European moratorium on GMOs (Attac France 2003b) - plans that were postponed at that time in view of the already strained relations between the USA and Europe due to the imminent war on Iraq.

The authors of the Académie des Sciences report were also criticized for their allegedly close personal relations with various business interests (Rhône-Poulenc / Aventis, Limagrain, the French seed industry confederation CFS, etc.), which presumably had severely compromised the independence of their judgment. Deputies of Attac at the National Assembly questioned the 'scientific objectivity' of the two reports and demanded the installation of a parliamentary committee of inquiry in order to investigate the 'conflicts of interest' that might have influenced their preparation (Attac France 2003a; Frat 2003). The authors of the reports, however, played down the importance of the adduced industrial connections and at any rate denied that these had biased their judgement. Professor Douce, for one, stated: "I am being attacked because I once led a research unit of CNRS / Rhône-Poulenc. That work ended in 1995 and since then I have not been involved in the development of GMOs. There is behind this entire affair an anti-GMO movement whose power I could not have imagined" (Frat 2003). He and his colleagues also claimed to have been harassed and threatened with violence: "[Douce] told Nature that such was the ferocity of the critical reaction that he would now think twice before giving public advice in the future" (Butler 2003). The president of the Academy of Sciences, Beaulieu, called on the French government to defend "the honour of scientists attacked in their mission of delivering independent and educated information to society" (Butler 2003). Indeed the ministers for research and technology and for national education, Claudie Haigneré and Luc Ferry, unreservedly condemned the personal attacks and the threats of physical intimidation as attempts to cast doubt on the moral and intellectual integrity of Academy members and to silence them (Agrisalon.com 2003).

It is indeed possible that the opponents of biotechnology have exaggerated the business connections of the authors of the Academy report and made too much of the ensuing conflicts of interest. Still this is a very sensitive issue. In order to maintain the public credibility of science sometimes even the mere semblance of relying on outside financial interests has to be avoided. Ironically, the report of the Academy of Sciences 
was thoroughly aware of this need for financial independence. It stated in the first chapter: "Maintaining a funding of research which guarantees a certain level of independence of the researchers with regard to economic imperatives is indispensable to preserve the credibility of risk assessment" (Académie des Sciences 2002, see Recommandations spécifiques aux chapitres ).

Attac France distanced itself from the personal attacks and physical threats directed at Roland Douce and the other authors of the two reports. The group clarified its position as follows: "ATTAC reaffirms its wish to see a real social debate being conducted on GMOs. ATTAC is by no means hostile to research on GMOs in a confined environment, but demands that tests in the open field be prohibited. As long as there are no scientific proofs demonstrating a total absence of risk, the precautionary principle must be applied" (Attac France 2003a). Here, a strong version of the Precautionary Principle (in what follows to be abbreviated as PP) is invoked. This version is entirely at odds with the tenor of the official report on the PP which Philippe Kourilsky and Geneviève Viney issued in 1999 to Prime Minister Jospin: "Precaution may not in fact be equated, on pain of misunderstanding the sense of the principle, with the unrealistic demand of zero risk" (Kourilsky and Viney 2000, p. 12).

Our quick scan of recent GMO controversies in France has shown a few things. There are deep divisions of mutual distrust between established scientific institutes and large segments of the population, especially environmentally concerned citizens. While the scientific and political establishment preaches the virtues of 'dialogue' and involving the general public, the outcomes of concrete attempts at participatory decision-making like organized social debates and citizen's conferences are not taken seriously if they deviate too much from the official commitment to biotechnology. Environmentalist groups in their turn are deeply suspicious of 'expert opinion' on GMOs even if it comes from what were formerly prestigious scientific institutions. Advisers are seen to follow a political agenda rather than stick to the bounds of their scientific competence. Due to more or less close relationships with external business partners that seem to characterize the contemporary life sciences, charges of 'conflicts of interest' are easily raised and extremely hard to rebut (for similar concerns with regard to GMO field trials in the UK, see Myhr and Traavik 2003, p. 241). While both sides on the debate about GMOs appeal to the so-called PP, each party attaches its own favoured meaning to it.

Most problematic is the precarious credibility of scientific expertise. Even the official Kourilsky-Viney report recognizes the fundamental difficulty of the situation: "Scientific expertise surely provides insights [des connaissances] at the service of decision-making, but in situations of precaution where it operates on the limits of knowledge, the expert does not know. On the basis of what he knows, he expresses an enlightened opinion or conviction, which is however not entirely free from prejudice. He therefore inevitably transgresses the limits of his own knowledge and may for that reason be readily contradicted by his own peers" (Kourilsky and Viney 2000, p. 61, italics mine). This situation is responsible for a large part of the public ambivalence towards scientific expertise in modern risk societies, as laypersons cannot rely on their own unaided senses but need the mediation of science and technology to chart the hazards and risks that may threaten their existence (Beck 1992). 


\section{Different views of precaution: the US, the EU and NGOs}

On 13 May 2003 the Bush administration announced that it would file a WTO case against the moratorium on genetically modified crops and foods that is de facto in force in the European Union since October 1998, when new approvals were frozen (Office of the United States Trade Representative USDA 2003). Earlier plans in that direction were stalled in the run-up to the war on Iraq. As many commentators had expected, the end of the military confrontation in Iraq signalled a new willingness on the part of the US government to initiate a major trade war: "If the United States and France continue to feud over Iraq, one place the Bush administration can be expected to seek revenge is the WTO" (Feffer 2003). Some commentators question the wisdom of this move, quite apart from the legal merits of the case: "[This] announcement is likely to play poorly in Europe, however, where many consumers already feel the U.S. government has been trying to shove gene-altered food down their throats" (Gillis 2003; see also Pew Initiative on Food and Biotechnology 2003). In the accompanying document to the announcement, US Trade Representative Robert Zoellick called the EU moratorium illegal, in violation of WTO rules and 'non-science-based': "Numerous organizations, researchers and scientists have determined that biotech foods pose no threat to humans or to the environment. Examples include the French Academy of Medicine and Pharmacy, and the French Academy of Sciences ..." (Office of the United States Trade Representative USDA 2003).

The US seems to have a very strong legal case to challenge the EU moratorium before the WTO, but European Commissioner David Byrne called the timing of the suit "a little eccentric" as the EU was already moving to lift the moratorium and replace it with new legislation on labelling and traceability (Reuters 2003). Of course, the US government would consider the new European rules on labelling and tracing of GM foods also to be unduly burdensome and costly to American farmers and exporters, and may in future be expected to challenge these in turn. However, such rules, if applied with consistency and without discrimination, would probably be much less vulnerable to a WTO challenge (Feffer 2003).

It is not likely that EU officials are going to take recourse to the PP in order to defend the moratorium; instead they will meet the WTO challenge with a lot of equanimity and move on to introducing legislation on labelling and tracing in order to ensure consumer choice. The real test case will be when the latter are also challenged; but in that event the dispute enters the ideologically charged domain of consumer choice where the US position is also vulnerable, because American consumers are de facto denied the choice of GM-free products (Pew Initiative on Food and Biotechnology 2003). According to an ABC News poll, 93 percent of Americans support labelling of genetically engineered foods (The Campaign 2003).

The US-EU disagreement over GMOs is just one episode in a longer series of disputes. Over the past decade or so, the European and American approaches to environmental, health, safety and consumer regulation have drifted further apart. Whereas during the 1970s and 1980s the US regulatory regime was generally much more strict and risk-averse than the European regime, the situation was reversed during the 1990s. In David Vogel's imagery, the hare and the tortoise changed places (Vogel 2003). After 1990, America started to move like a tortoise when a conservative pro-business majority in the Republican Party blocked further regulatory initiatives, helped by the fortunate absence in the US of major incidents such as the mad-cow disease, the HIV-contaminated blood scandal (especially in France) and a number of food scares which in Europe undermined the confidence and trust of citizens and 
consumers in their regulatory authorities. The creation of a single European market necessitated the strengthening of regulatory standards: a high level of health and environmental protection was critical to the legitimacy of a growing bureaucracy in Brussels. Simultaneously, the process of policy-making became more open and accessible to non-business constituencies. Already the Maastricht Treaty of 1992 declared the PP to be a key principle of Community environmental policy; in due course, this very principle would become the avowed cornerstone of EU regulation in the areas of food safety, environment, human health, animal health and plant health.

All the while the US government has been sceptical of the so-called PP, suspecting that it may be used too easily as an excuse for protectionism. The European Union had indeed invoked this principle to defend the ban on hormone-treated-beef imports from the United States, which the latter successfully challenged before the WTO (Charlier and Rainelli 2002). The US government is prone to counter any invocation of the PP with a mantra-like appeal to 'sound science' and to the fairly narrow provisions of the SPS agreement of the WTO (SPS stands for sanitary and phytosanitary measures). The implied suggestion is that the PP goes beyond sound science and is therefore arbitrary. In February 2000, the Commission of the European Communities issued a communication on the PP to strengthen its policy position in order to defend the EU better from future legal challenges by other WTO members (European Commision 2000).

The Commission argued that, regardless of divergences in the used terminology, the PP had already become a rule of customary international law in the areas of health and environmental protection. The Commission referred, inter alia, to the North Sea Declaration (1987), the Rio Declaration (1992), the preamble of the Convention on Biological Diversity (1992), the Convention of Climate Change (1992) and the Protocol on Biosafety (2000). A well-known formulation of the 'precautionary approach' is to be found in Principle 15 of the Rio Declaration: "Where there are threats of serious or irreversible damage, lack of full scientific certainty shall not be used as a reason for postponing cost-effective measures to prevent environmental degradation". Another well-known but unofficial definition of the PP, not quoted in the Commission's communication, was spelled out in a January 1998 meeting at Wingspread in Racine, Wisconsin. The Wingspread Statement summarized the principle thus: "When an activity raises threats of harm to human health or the environment, precautionary measures should be taken even if some cause and effect relationships are not fully established scientifically" (Raffensperger and Tickner 1999, p. 353-354). In the communication, the Commission declined to give a precise definition of the PP, arguing that the meaning of the concept will be fleshed out by decision-makers and courts of law. Still the Commission offered in rather convoluted prose what looked like the rudiments of a definition: "[The Precautionary Principle] covers those specific circumstances where scientific evidence is insufficient, inconclusive or uncertain and there are indications through preliminary objective scientific evaluation that there are reasonable grounds for concern that the potentially dangerous effects on the environment, human, animal or plant health may be inconsistent with the chosen level of protection" (European Commision 2000, p. 10). This formulation alludes to 'the chosen level of protection' because the Commission held that each WTO member has the independent right to determine the level of environmental or health protection they consider appropriate (p. 11). The Commission also introduced a sharp distinction between 'risk assessment' and 'risk management', that is, between science and politics. Whereas a 'prudential approach' may be part of (scientific) risk assessment (e.g. by taking into account a pre-defined safety margin in 
risk evaluation), the application of the $\mathrm{PP}$ is held to belong to (political) risk management. Risk management is the preserve of political decision-makers, according to the Commission: "Judging what is an 'acceptable' level of risk for society is an eminently political responsibility" (European Commision 2000, p. 4). It would appear that deciding on an acceptable level of risk is just the flip-side of choosing a certain level of protection. The Commission further held that application of the PP has to satisfy customary procedural criteria like proportionality, non-discrimination, consistency, examination of potential costs and benefits, review and assignment of responsibility. Through the thicket of added qualifications it is rather difficult to discern what the PP basically stands for.

Existing definitions and formulations of the PP - and there are many - all tend to beg the crucial questions. Is there ever full scientific certainty or sufficient, conclusive and fully certain scientific evidence? In other words, wouldn't it be possible to invoke the PP on each and every occasion? Do we need a minimal threshold of scientific certainty or plausibility before we may (or should) undertake preventative action? How strong must the 'indications' and the 'reasonable grounds' be before we should do something about the presumed threat (but remember that we have by definition only preliminary evidence!)? And do we really know how to prevent harm if we are so much ignorant about the underlying cause-effect relationships? The definitions that are currently on offer fail to spell out the precise conditions that have to be fulfilled before the PP may be invoked or the nature of the preventative action that has to be taken. The types of action suggested range from implementing a ban, imposing a moratorium while further research is conducted, allowing the potentially harmful activity to proceed while closely monitoring its effects, to just conducting more research. The PP does not have a very precise meaning as long as such crucial aspects are left largely unanswered.

A specific problem with the communication of the European Commission is that it does not offer us any guidance on how we should go about bridging the gap between the scientific risk assessment and the policy objectives of risk management, i.e., the effective realization of a chosen level of protection (or an acceptable risk level). Does it make sense at all, if there is so much scientific uncertainty, to think in terms of realizing specific levels of protection?

Unlike the European Commission, many environmentalist NGOs do not subject the application of the PP to a series of additional procedural criteria. In practice, this often means that the PP is given a more definite meaning by effectively reducing it to an absurdity. Normally no minimal threshold of plausibility is specified as a 'triggering' condition, so that even the slightest indication that a particular product or activity might possibly produce some harm to human health or the environment will suffice to invoke the principle. And just as often no other preventative action is contemplated than an outright ban on the incriminated product or activity. Greenpeace provided a clear example of this approach when it rang alarm bells after a team at Cornell University showed in 1999 that monarch butterfly larvae exhibited increasing morbidity and mortality when fed in the laboratory with milkweed leaves dusted with pollen from transgenic Bt-maize (for a more extensive analysis of this case, see Van den Belt 2003). For Greenpeace it was immediately clear that monarch butterfly populations in the wild, and one hundred other species of butterflies as well, were gravely endangered by the growing of genetically engineered maize and of all other transgenic crops. The NGO therefore demanded an immediate stop to these practices. It was later found that monarch butterfly populations in the American Mid-West, 
where transgenic maize is cultivated on a large scale, were not affected at all (Ortman et al. 2001).

Closely linked to various versions of the PP is the idea of reversing the onus of proof. Thus the adherents of the Wingspread Statement declare that "the applicant or proponent of an activity or process or chemical needs to demonstrate that the environment and public health will be safe. The proof must shift to the party or entity that will benefit from the activity and that is most likely to have the information" (Raffensperger and Tickner 1999, p. 345-346). Greenpeace also holds that effective implementation of the PP requires a shift in the burden of proof (Greenpeace International 2001). In its communication the European Commission maintains that action under the head of the PP sometimes implies reversing the onus of proof, but that such reversal cannot be the general rule (European Commision 2000, p. 21). Shifting the burden of proof seems a fairly straightforward way to ensure, as the German philosopher Hans Jonas demanded, that greater weight will be given to the 'prognosis of doom' than to the 'prognosis of bliss' (Jonas 1984, p. 34).

The PP is sometimes also associated with the idea that the introduction of a new technology like genetic modification needs the 'informed consent' of the population and therefore requires open, transparent and democratic processes of decision-making before commitments have been made to research, development and marketing (Barrett 2000). The European Commission also gestures towards the need to ensure a wider and more active participation by the public, and even a biotech company like Monsanto nowadays makes a solemn 'pledge' to engage in dialogue and move in step with a large array of 'stakeholders'. To me the question of democratic decisionmaking about technology is a special issue that is perhaps better kept apart from the PP. It raises questions of its own, such as: How seriously do we take the idea of 'informed consent'? Are we willing to grant veto power to minorities who remain tenaciously opposed to a technology that the majority wants to embrace? Is this compatible with the existence of a 'free' market economy? One way to link the PP with public participation is to reason that we need to broaden the process of decisionmaking because, due to the fundamental scientific uncertainties with which we are confronted, 'the expert does not know' (cf. the earlier quotation from Kourilsky and Viney 2000; - this line of reasoning is followed by Testart 2000). Myhr and Traavik (2003, p. 242) also argue for expanded peer-review processes and extended peer communities as a mechanism to balance scientific advice with the involvement of other parties. If the experts do not know, then everybody supposedly becomes an expert. But will a more open and democratic decision-making process on biotechnology by itself resolve the underlying uncertainties?

\section{The strong version of the PP}

According to the strong version of the PP the mere prospect of potentially harmful effects of a new technology is enough to stop its introduction and deployment. But why should the prospect of harmful effects take precedence over the prospect of beneficial effects, quite apart from the inherent likelihood of each of these possibilities? The obvious answer seems to be that such a priority is defensible only when the harmful effects are of such magnitude that they carry catastrophic (or, as Jonas would say, 'apocalyptic') potential. The infinite costs of a possible catastrophic outcome necessarily outweigh even the slightest probability of its occurrence.

It is, however, not difficult to see that the strong version of the PP - also dubbed the 'catastrophe principle' - is logically untenable (for the analogy of this version with 
Pascal's famous but equally untenable 'wager argument' for believing in the existence of God, see Van den Belt 2003). Take the application of this principle to the problem of global warming. Environmentalists often argue that even if it is not conclusively established that the emission of carbon dioxide and other gases causes an enhanced greenhouse effect, the mere prospect of an ecological catastrophe due to such a scenario should lead us to curb our emissions of greenhouse gases drastically now. By the same logic, however, one could conjure up the possibility of a coming ice age. The mere prospect of this equally catastrophic scenario should then induce us to avert this outcome by stepping up the emission of greenhouse gases. The strong version of the PP would thus lead to contradictory recommendations. In a similar way, it could be argued that this principle commits us to each of two contradictory policies: (1) we must not develop GM crops, and (2) we must develop GM crops. The first alternative is argued vehemently by many environmentalists who appeal to the PP. To support the second possibility, Gary Comstock conjures up a dramatic scenario in which people are forced to seize upon the remaining reserves of nature in a desperate effort to overcome food shortages resulting from global warming. He then argues, in the style of the environmentalists, that "lack of full scientific certainty that GM crops will prevent environmental degradation shall not be used as a reason for postponing this potentially cost-effective measure" (Comstock 2000).

\section{Reversing the burden of proof?}

So the strong version of the PP is untenable. But what about the proposed shifting of the onus of proof towards those who advocate a new technology or activity? Reversing the burden of proof would amount to substituting the maxim 'guilty until proven innocent' for the age-old legal principle 'innocent until proven guilty'. Biotech enthusiasts and anti-regulationists resent this departure from what they consider timehonoured legal sanity (Miller and Conko 2000). They are prone to counter the frequent invocation of the PP with an equally insistent demand of 'sound science'. While one side claims the moral high ground, the other side attempts to seize the scientific high ground.

The critics of the PP assert that the burden that environmentalists and regulators want to impose on the proponents of new technologies tends to be unbearable (Miller and Conko 2000). In the name of absolute safety the latter are asked nothing less than to demonstrate conclusively that the new technologies they advocate offer no possible harm. This is a formidable, perhaps even logically impossible task. You cannot prove a negative (cf. Wildavsky 1995, p. 430). Moreover, a risk-free world is not a real option. Thus a consistent application of the PP would in the final analysis stifle all innovation.

Should we therefore follow the adage 'innocent until proven guilty'? Even in the area of criminal justice we do not use this principle in an absolutist way. We may try to reduce the risk of condemning an innocent person by demanding ever more exacting standards of proof, but only at the expense of increasing the risk of acquitting culpable offenders. So we must recognize that there is an inevitable trade-off involved in the design of our system of criminal justice. We may attempt to set our standards as high as we can, but somewhere a balance must be struck, lest the system will become unworkable by making it too difficult to pass sentence on the majority of wrongful offenders. (In statistical testing there is a similar trade-off to be made between the chances of committing a type-I or a type-II error, i.e. rejecting the null hypothesis of 'no effect' when it is in fact true or failing to reject the null hypothesis when in fact it 
is false. By selecting a significance level we implicitly strike a particular balance. Ideally, this balance should depend on our estimation of the - economic and other costs associated with either of the two types of error.)

The above analysis shows that the matter at issue is not just where to place 'the' burden of proof. As soon as we allow for more or less exacting standards of proof, an extra dimension of variation immediately becomes visible. In other words, the burden we want to put on the shoulders of one or the other party becomes more or less heavy, depending on whether we set our standards of proof more or less high. This consideration may help us to escape from the unduly polarized opposition of PP versus sound science.

In most countries, companies aiming to commercialize GM crops have to submit their products to scrutiny for health effects and environmental impacts. This scrutiny can be more or less searching. The ideal of those who swear by 'sound science' is a fully quantified risk assessment. However, it is only possible to meet this objective in more limited contexts, where direct and short-term hazards such as toxicity or pathogenicity are at issue. Even then the expression 'sound science' is disingenuous, for it obscures the extra-scientific value judgments that necessarily enter into the whole exercise, e.g. identification of hazard types, pathways of exposure, baselines of acceptability, trade-offs between type-I and type-II errors (see also Thompson 2003). In other contexts, where indirect, cumulative or more subtle ecological effects are at issue, the format of the fully quantified risk assessment is unattainable. Adherents of 'sound science' are tempted to downplay such less straightforward hazards as purely hypothetical risks that can safely be ignored. However, as the proponents of the PP are never tired in pointing out, lack of evidence of harm is not evidence of lack of harm. If we are really concerned about such hazards, we can put in additional investigative effort to learn more about their plausibility or likelihood. It would be absurd to halt our inquiries with an appeal to 'sound science'.

\section{The wider context}

A recent European directive on the deliberate release of GMOs into the environment lays down that any company that wants to introduce or commercialize a transgenic crop should carry out a 'full' environmental risk assessment taking into account 'direct, indirect, immediate and delayed effects' (European Commission 2001). This new regulation of GM crops goes much further than current US registration requirements, although some American biologists also argue for a more comprehensive approach (Obrycki et al. 2001).

The new European Directive surely places a heavy burden of proof on biotech companies intending to introduce GMOs. Whether or not they are able to take that burden on their shoulders will partly depend on the definition of a standard protocol or methodology for conducting environmental risk assessments. The danger to be avoided is that the obligations imposed on these companies will become 'open-ended', putting them entirely at the mercy of regulatory agencies and NGOs asking for everescalating assurances of environmental safety. This suspicion will be enhanced by the fact that the drafting of the Directive has avowedly been informed by the PP and that regulatory authorities may give consent to the introduction of GMOs only after they have been satisfied that the release will be safe for human health and the environment.

The fairly comprehensive scope of the required environmental-risk assessment need not be offensive in itself, if rules of fair play for the regulation of GM crops can be developed. More clarity is also needed about the societal values that have to be 
taken into account in evaluating risks. The outcome of the assessment is clearly contingent, for instance, on whether or not chemical-intensive methods in agriculture are taken as a normative baseline or whether or not a strong commitment to organic agriculture as a viable option is maintained (Levidow 2001; Myhr and Traavik 2003). The pros and cons of a $B t$ maize hybrid or any other transgenic crop in Europe might be quite different from those in the USA. Europeans are usually strongly attached to farmland, as their countries lack vast tracts of national parks and other 'wilderness' areas (Hails 2002). Indeed, Willy de Greef, head of regulatory affairs at Syngenta Seeds, holds that the debate in Europe on GM foods is not fundamentally about safety, but is in fact a proxy for a larger debate on how farming should be done (Hileman 2001). GM crops have become a symbol for all that Europeans do not like in modern agriculture. John Feffer sees an even deeper 'clash of civilizations' behind the US-EU dispute on GMOs, formulaically described as 'terroir versus McWorld'. 'Terroir' stands for the (French) belief that conditions such as soil and weather produce distinctive tastes. "In Europe, people want to know how their food was raised and made. For quality control, they generally trust farmers over biotechnicians" (Feffer 2003).

While the European Union may eventually opt for a combination of organic and conventional farming and a rather limited acceptance of agricultural biotechnology only insofar as the latter is compatible with a 'co-existence' regime -, the critical question is whether this strategy also makes sense on a global scale. It is not surprising that Greenpeace International offers us the option of organic farming as a worldwide solution. However, several agronomic experts argue that we shall badly need all the various tools of modern biotechnology to feed a growing world population and sustain natural biodiversity (Trewavas 1999; Conway and Toenniessen 1999). The ecologist's response is that thermodynamic considerations make it unlikely that GM plants can actually increase food production and, at the same time, repel pests, resist herbicides and compete with weeds for water and nutrients for any prolonged period of time (Jordan 2002). Although the scientific debate is somewhat technical and esoteric, the stakes are clearly high.

It thus appears that the polarized debate on the PP is just a proxy for a larger debate on the future of world agriculture.

\section{References}

Académie des Sciences, 2002. Les plantes génétiquement modifiées, Paris. Rapport sur la Science et la Technologie no. 13.

Agrisalon.com, 2003. Claudie Haigneré et Luc Ferry dénoncent "des attaques inadmissibles contre les scientifiques" (10/02/2003). [http://www.agrisalon.com/06-actu/article-9352.php]

Attac France, 2003a. OGM: la nostalgie de la cohabitation. Deux ministres du gouvernement Raffarin et un député socialiste font, au même moment, des déclarations de soutien au lobby pro-OGM (12/02/2003). [http://france.attac.org/a1804]

Attac France, 2003b. Quand l'Académie des Sciences vole au secours des industriels et de l'administration Bush (15/01/2003). [http://france.attac.org/a1701]

Barrett, K., 2000. Applying the Precautionary Principle to agricultural biotechnology. Science and Environmental Health Network. [http://www.biotechinfo.net/PP_Barrett.pdf]

Beck, U., 1992. Risk society: towards a new modernity. Sage, London. 
Butler, D., 2003. Ministers back gene-crop advisers. Nature, 421 (6925), 775.

Charlier, C. and Rainelli, M., 2002. Hormones, risk management, precaution and protectionism: an analysis of the dispute on hormone-treated beef between the European Union and the United States. European Journal of Law and Economics, 14 (2), 83-97.

Comstock, G., 2000. Are the policy implications of the Precautionary Principle coherent? : viewpoints.

[http://www.cid.harvard.edu/cidbiotech/comments/comments72.htm]

Conway, G. and Toenniessen, G., 1999. Feeding the world in the twenty-first century. Nature, 402 (suppl.), C55-C58.

European Commision, 2000. Communication from the Commission on the Precautionary Principle, Brussels, 02.02.2000, COM (2000) 1, Brussels. [http://europa.eu.int/comm/dgs/health_consumer/library/pub/pub07_en.pdf]

European Commission, 2001. Directive 2001/18/EC of the European Parliament and of the Council of 12 March 2001 on the deliberate release into the environment of genetically modified organisms and repealing Council Directive 90/220/EEC. Official Journal of the European Communities, L106/1 E, 17/4/2001, 1-38. [http://europa.eu.int/eurlex/pri/en/oj/dat/2001/1_106/1_10620010417en00010038.pdf]

Feffer, J., 2003. Trans-Atlantic food fight: the stakes in the U.S.-Europe battle over genetically engineered crops. American Prospect, 14 (5). [http://www.prospect.org/print/V14/5/feffer-j.html]

Frat, M., 2003. Les scientifiques soupçonnés de conflit d'intérêt contre-attaquent. Le Figaro (12 February 2003).

Gillis, J., 2003. Suit to seek end of biotech crop ban. Washington Post (May 13, 2003), A13. [http://www.washingtonpost.com/wp-dyn/articles/A471972003May 12.html]

Greenpeace International, 2001. Safe trade in the 21st century: the Doha edition. Greenpeace International, Amsterdam.

[http://www.greenpeace.org/politics/wto/doha_report.pdf]

Hails, R.S., 2002. Assessing the risks associated with new agricultural practices. Nature, 418 (6898), 685-688.

Hervieu, B. and Guillou, M., 2002. Oui aux OGM aux champs. Libération, 23 September 2002.

Hileman, B., 2001. Polarization over biotech food. Chemical and Engineering News, 79 (21), May 21.

Inf'OGM, 2002. OGM: Opinion Grossièrement Manipulée? October 2002. [www.infogm.org]

Jonas, H., 1984. The imperative of responsibility: in search of an ethics for the technological age. The University of Chicago Press, Chicago.

Jordan, C.F., 2002. Genetic engineering, the farm crisis, and world hunger. BioScience, 52 (6), 523-529.

Kourilsky, P. and Viney, G., 2000. Le principe de précaution. Odile Jacob, Paris.

Levidow, L., 2001. Precautionary uncertainty: regulating GM crops in Europe. Social Studies of Science, 31 (6), 842-874.

Miller, H.I. and Conko, G., 2000. The science of biotechnology meets the politics of global regulation. Issues in Science and Technology, 17 (1), 47-54.

Myhr, A.I. and Traavik, T., 2003. Genetically modified (GM) crops: precautionary science and conflicts of interest. Journal of Agricultural and Environmental Ethics, 16 (3), 227-247. 
Obrycki, J.J., Losey, J.E., Taylor, O.R., et al., 2001. Transgenic insecticidal corn: beyond insecticidal toxicity to ecological complexity. BioScience, 51 (5), 353361.

Office of the United States Trade Representative USDA, 2003. U.S. and cooperating countries file WTO case against EU moratorium on biotech foods and crops: EU's illegal, non-science based moratorium harmful to agriculture and the developing world. 13 May 2003. [http://www.ustr.gov/releases/2003/05/0331.pdf]

Ortman, E.E., Barry, B.D., Buschman, L.L., et al., 2001. Transgenic insecticidal corn: the agronomic and ecological rationale for its use. BioScience, 51 (11), 900903. [http://www.bioone.org/pdfserv/i0006-3568-051-11-0900.pdf]

Pew Initiative on Food and Biotechnology, 2003. Should the U.S. press a WTO case against Europe's genetically modified food policies? (Originally broadcast live on February 13, 2003). [http://www.mindfully.org/GE/2003/US-PressWTO-GMOs13feb03.htm]

Raffensperger, C. and Tickner, J.A. (eds.), 1999. Protecting public health and the environment: implementing the Precautionary Principle. Island Press, Washington DC.

Reuters, 2003. EU says a US attack over GMOs would be 'eccentric'. 13 May 2003. [http://www.planetark.com/dailynewsstory.cfm/newsid/20770/story.htm]

Testart, J., 2000. How to let ordinary people in on the future: be careful, take precautions. Le Monde Diplomatique (English version) (September 2000).

The Campaign, 2003. GE foods tutorial: why labeling? [http://www.thecampaign.org/education/brochurelabels.htm]

Thompson, P.B., 2003. Value judgements and risk comparisons: the case of genetically engineered crops. Plant Physiology, 132 (1), 10-16.

Trewavas, A., 1999. Much food, many problems: a new agriculture, combining genetic modification technology with sustainable farming, is our best hope for the future. Nature, 402 (6759), 231-232.

Van den Belt, H., 2003. Debating the Precautionary Principle: "guilty until proven innocent" or "innocent until proven guilty"? Plant Physiology, 132 (3), 11221126.

Vogel, D., 2003. The hare and the tortoise revisited: the new politics of consumer and environmental regulation in Europe. British Journal of Political Science, 33 (4), 557-580.

Wildavsky, A., 1995. But is it true? A citizen's guide to environmental health and safety issues. Harvard University Press, Cambridge. 